\title{
REFLECTION OF WOMEN'S OPPRESSION IN THE WRITINGS OF QURUT-UL-AIN HAIDER: A SOCIOLOGICAL ANALYSIS
}

\author{
Naila Usman Siddiqui \\ Munazza Madani** \\ Sabahat Raza**
}

\begin{abstract}
This study analyzed the concept of women's status and oppression as depicted in the writings of one of the famous fiction writers in Urdu literature named Qurat-ul-Ain Haider. ${ }^{1}$ It was a qualitative research study and was based on a sociological analysis of a selected set of stories of the writer. Four stories were chosen from Qurat-ul-Ain Haider's writings for content analysis. This study reflected the socio-cultural values regarding status of women in the Indian Subcontinent. ${ }^{2}$ It facilitated in understanding women's oppression specifically with reference to the culture in the then Subcontinent. The concept of women's oppression in the specific context of the literature emerged in the form of low status of women, gender oppression, patriarchal cultural values, and social injustice towards women. The writings of Quratul-Ain-Haider are to date relevant in understanding of the status and subordination of women in South Asia and can serve as a contribution to Feminist Sociology within a specific cultural context.
\end{abstract}

Keywords: Women's oppression, feminist sociology, patriarchy, social injustice, gender discrimination

\section{Introduction}

Oppression is the inequitable use of authority, law, or physical force to prevent others from being free or equal. Oppression is a type of injustice. The verb oppress can mean to keep someone down in a social sense. ${ }^{3}$

There are different forms of women's oppression in different societies. The biological difference between men and women has been considered the main reason of oppression of women, division of labor and subjugation, throughout history. Feminists fight against the oppression of women. Women have been unjustly held back from achieving full equality in many societies around the world.

\footnotetext{
* Naila Usman Siddiqui, Ph.D., Associate Professor, Department of Sociology, University of Karachi

${ }^{* *}$ Munazza Madani, Ph.D., Assistant Professor, Department of Sociology, University of Karachi

${ }^{* * * *}$ Sabahat Raza, M.Phil. Scholar, Area Study Centre for Europe, University of Karachi

${ }^{1}$ Born in 1927, in the Indian Subcontinent, Qurut-ul-AinHaider was one of the most popular fiction writers of Urdu literature. She belonged to a very literate family with both her parents being famous short story writers. Haider did her Masters in English and wrote novels and short stories that were published in top digests and journals.

${ }^{2}$ The Indian Subcontinent was one of the nations under the British rule. In 1947 after the war of Independence, the Indian Subcontinent was divided into two separate nations namely Pakistan and India.

${ }^{3}$ Napikoski, L. and Lewis, J.J. Oppression and women history. (2019), Available at www.thoughtco.com
} 
Feminist theorists of the 1960s and 1970s looked for new ways to analyze this oppression, often concluding that there were both overt and insidious forces in society that oppressed women. These feminists also drew on the work of earlier authors who had analyzed the oppression of women, including Simone de Beauvoir in "The Second Sex" and Mary Wollstonecraft in "A Vindication of the Rights of Woman".

Quaratul Ain Haider is one such Urdu writer who wrote boldly and openly on issues of gender inequality, discrimination and oppression, her writings are set in the time frame of post- Independence Indo Pakistan Subcontinent. In this paper four of her stories were chosen for content analysis, written during 1940 and 1960.

\section{Women's Oppression is Ubiquitous}

In much of the written literature of the ancient and medieval world, we have evidence of women's oppression by men in European, Middle Eastern, and African cultures. Women did not have the same legal and political rights as men and were under control of fathers and husbands in almost all societies. ${ }^{5}$

In some societies in which women had few options for supporting their life if not supported by a husband, there was even a practice of ritual widow suicide or murder. Asia continued this practice into the 20th century with some cases occurring in the present as well. ${ }^{6}$

In Greece, often held up as a model of democracy, women did not have basic rights, and could own no property nor could they participate directly in the political system. In both Rome and Greece, women's every movement in public was limited. There are cultures today where women rarely leave their own homes. In some societies in which women had few options for supporting their life if not supported by a husband, there was even a practice of ritual widow suicide or murder. ${ }^{7}$

\section{Glimpses of Feminism in the Great Britain in $20^{\text {th }}$ Century}

Though, women around the globe were fighting for their rights for a long time but it was $20^{\text {th }}$ century when the world saw a lot of women coming out of their four walls in order to fight against social injustice against them. According to Brose (2005), in 1908, 250,000 women were gathered at Hyde Park in order to demand voting rights. Who can forget Emily Davison who sacrificed her life for the cause by stepping onto the racing track in front of King's race horse. ${ }^{8}$

The First World War had also a great impact on the status of women. While men were out for war, they were replaced by women. According to Brose (2005) "In Britain, hundreds of thousands of women filled positions in local and national government and

\footnotetext{
${ }^{4}$ Ibid. p. 3

${ }^{5}$ Ibid.

${ }^{6}$ Ibid. p.5

${ }^{7}$ Ibid. p.7

${ }^{8}$ Eric, D. Brose, A History of Europe in the Twentieth Century (New York: Oxford University Press, 2005), 57.
} 
volunteered as auxiliaries in the army, navy, air force, and police corps and doctors, nurses and hospitals orderlies. Others performed charitable work in private organizations." But unfortunately as soon as war ended and soldiers returned they took back their jobs and women were again pushed into the walls. ${ }^{9}$

British women won their voting rights in 1918, but societies were not ready to let women live according to their will. Simone De Beauvoir wrote in her essay that the customs of our world does not allow women to live according to her will ${ }^{10}$

This was not the only case; there were other issues such as discrimination in wages, education and health etcetera. According to Cochrane (2013) "In 1970, women organized a protest at the annual Miss World contest in London; that same year, the first National Women's Liberation Conference formulated demands for equal pay, equal education and opportunity, 24-hour nurseries, free contraception and abortion on demand. ${ }^{11}$

\section{Evolution of Feminism in Sub-Continent}

In ancient India women's status was slightly high. According to Nandal and Rajnish (2014) "In the Rig Vedic Period women used to take part in the intellectual life of the society. They were used to devote their time, till their marriage, to specialize in Vedic theology and philosophy.",

This claim is supported by Halli and Mullal (2016). According to Halli and Mullal (2016) in ancient times Indian women were free and used to participate in many spheres of life but after 500 B.C. this status of women was gradually declined. ${ }^{13}$ Sharma (2006) also wrote that in Vedic period women were regarded as mother goddesses and they were enjoying a respectable place in society. Through documents it is evident that Indian women enjoyed their equal status by Rig-Vedic period but this status was deteriorated in Puranic Era. ${ }^{14}$

In 1213, Sultan Altamash, a Muslim ruler chose her daughter Razia Sultana as her successor in the presence of his three sons because he believed that Razia was far educated ,intelligent and mature than his sons. Mughal emperor Babur's grandmother Ahsan Daulat Begum guided Babur in government affairs and she remained his advisor till her death. Likewise Queen Noor Jahan was the popular queen of the Sub-Continent.

${ }^{9}$ Ibid.

${ }^{10}$ Kishwar Naheed,Aurat: Zaban e Khalq se Zaban e HaalTak. (Lahore: Sang-e-Meel Publications, 2010).

${ }^{11}$ Cochrane, Kira. "1963: The Beginning of the Feminist Movement." The Guardian, May, 07, 2013. Accessed in February 5, 2018.

${ }^{12}$ Nandal, Vikas, Rajnish, M. (2014) "Status of Women through Ages in India" International Research Journal of Social Sciences, Volume 3, pp. 21-26.

${ }^{13}$ Halli, Chandarkala S. and Mullal, Shridhar M. "Status of Women in India Status of Ancient, Mediaeval and Modern." Imperial Journal of Interdisciplinary Research (IJIR), 2, 2016: 297-300. Retrieved from http://www.onlinejournal.in

${ }^{14}$ Sharma, Achla. "Status of Women: A Socio-Historical Analysis in Different Ages of Indian Society."

Research Journal of Literature, Language and Humanities, 1 (01), 2014: 10-14. Retrieved from www.isca.in. 
It is said that she used to sign the royal documents with her husband as well as her name was printed on coins. ${ }^{15}$

But these were few cases and all these women belonged to elite class. Freedom was out of question for middle, lower middle and lower class women, also most of elite women were leading an oppressed life. Indo Pakistan Sub-Continent was a typical patriarchal society. Women of Sub-Continent, regardless of age, religion, caste and class were suffering from social injustice and gender discrimination. A Hindu woman was burned alive with her dead husband while a Muslim woman had to live like a dead after the death of her husband. Child marriages were common. Women were sold. She had to cover herself. There was no concept of female education; it was purely a man's world. These cultural practices were carried out in the name religion.

Dr. Mubarak Ali (2014) wrote that Indian women completely lost their status in medieval period. The only objective of women's lives was to be married and produce boys. ${ }^{16}$

According to many historians it was British regime that helped women to upgrade their status. Ali (2014) claims that struggle of women's rights in India started during British rule. British invasion brought many changes in Indo Pakistan Sub-Continent. ${ }^{17}$

The greatest positive change occurred during British rule was the enlightenment and an increase in educational activities. Men, who were educating brought liberal ideas to the Sub-continent. "Large number of Indians being educated in England, USA and other Western centers were bringing home the ideas of liberalism". ${ }^{18}$ These men greatly influenced the history of Sub-continent, as they changed the whole scenario of India. They were few in numbers but they educated their women and these women played their Parts in educating other women.

Changes occurred fast in post-1857 India. British rulers made laws against sati, polygamy and child marriages, liberal and modern Indian men supported these ideas. The voice on female education was raised, but there were few women who were educated and they were given education within their home. Only traditional skills were imparted and only religious and moral lessons were considered important for women. History, geography, or science was considered useless. Languages of aristocracy Arabic and Persian were taught to few privileged and fortunate females who had some liberal patronage in their families. The details of good quality madrassas for girls, however, should not mislead us, as their impact was minuscule and the literacy among females was far below one per cent. ${ }^{19}$

Hina (2004) wrote that British rule was rapidly changing the Hindustani society and Muslim aristocracy was scared of this modernism. So there came Urdu literature that

\footnotetext{
${ }^{15}$ Fatima Hasan, Zahida Khatoon Sherwaniya: Hayat o Shayari Ka Tehqiqi aur tanqeedi Jaiza. (Karachi: A.G. Printing Services, 2014), 43.

${ }^{16}$ Mubarak Ali, Tareekh aur Aurat. (Lahore: Tareekh Publications, 2014), 36.

${ }^{17}$ Ibid. p.39

${ }^{18}$ Shaheen, Anwar. "Patriarchal Education and Print Journalism: Their Emancipating Impacts on Muslim Women of India During 1869-1908." Pakistan Journal of History and Culture. XXX(2), 2009: 1-42.

${ }^{19}$ Ibid.
} 
defended the patriarchal system and wanted to turned women into a loyal housewife. So the writers like, Khwaja Hassan Nizami, Allama Rashidul Khairi, Majnoon Gorakhpuri, Deputy Nazeer Ahmed etcetera were emerged to protect patriarchy. ${ }^{20}$

The dawn of $20^{\text {th }}$ century brought a list of female writers who penned down the problems and tragedies of women of Sub-Continent. Rokaya Sakhawat Hossien, Attiya Faizi, Hijab Imtiaz Ali, Nazar Sajjad Haider are among them. History cannot forget the name of Zahida Khatoon Sherwaniya for her feminist writings. She was a politically mature poetess and this maturity reflected in her letters that she wrote to her friend Laila Bano. She formed 'Anjuman e Moin e Niswan' by including her brothers, sisters and cousins, when she was only 12 years old. ${ }^{21}$

Iqbal-un-Nisa Husain was another progressive woman. She wrote a number of essays regarding woman's social status. In one of her remarkable essay she wrote against polygamy is remarkable. She wrote "Monogamy is the rule in Islam. Polygamy is only an exception allowed under certain conditions". ${ }^{22}$

Women were not encouraged to write literature as writing literature was considered not worthy of ladies. But, Progressive writers' movement of India brought such bold women writers like Dr. Rasheed Jahan, Ismat Chughtai and Razia Sajjad Zaheer. These women came up with and wrote on slightly bold issues like, marital rape, homosexuality, prostitution and maternal problems. This was the revolutionary step in Urdu literature. Qurut-ul-ain Haider was born and brought up in this scenario and amazingly she stood apart from progressive writers as well as from traditional ones.

\section{Literature Review}

Literature on the writings of Qurat-ul-Ain Haider mostly focuses on the literary aspects of her writings. Khan, Mansoor and Latif studied Qurat-ul-Ain Haider's short story, The Sound of Fallen Leaves and the application of stylistic devices in it. The sound of fallen leaves is a story based on the life of a middle class girl who destroys her life in order to elevate her status. They explored how well stylistic devices such as simile, hyperbole, prolepsis, ratiocinative question, rhetorical question, exclamation mark, important quotations and claque are applied by Haider in that story. ${ }^{23}$

According to Sajjad, Haider novels, Aag Ka Darya, Gardish-e-Rang-e-Chaman and her autobiographical novel Kaar-e-Jahan Daraz hai are historical in nature. Her novel Gardish-e-Rang-e-Chaman, portrays the lives of two princesses of Red Fort who ended

\footnotetext{
${ }^{20}$ Hina, Zahida. Aurat: Zindagi Ka Zindan (Karachi: The Sami Sons Printers, 2004), 53.

${ }^{21}$ Fatima Hasan,Feminism Aur Hum: Adab Ki Gawahi (Karachi: Wada KitabGhar, 2013), 59.

${ }^{22}$ Hussain, Iqbalunnisa . Changing India: A Muslim Woman Speaks (Pakistan: Oxford University Press, 2015), 66.

${ }^{23}$ Khan, Bari, A., Mansoor, Hafiza S. Latif, Mohsin. "The Application of Stylistics Devices on the Short Story the Sound of Fallen Leaves by Qurut-ul-AinHaider.” The English Literature Journal, 03 (03), 2016: 624-626.
} 
up as prostitutes after 1857. Sajjad (2011) also explored that Haider's most popular novel Aag Ka Darya covers the history of 2000 years of Indian society. ${ }^{24}$

Oldfield claims that Haider's, Aag Ka Darya and River of Fire are two different novels. According to him "The attentive reader of River of Fire may notice on the title page that it has been Trans created from the original Urdu by the author, and the very attentive reader may notice the substantial time gap between the 1959 original and the 1998 transcreation. ${ }^{25}$

Irtiza Kareem analyzed Haider's earliest novel Mere Bhi Sanam Khanay. Kareem claims that this novel is the symbol of the downfall of feudal system in Oudh. He analyzed that in this novel the author focuses on the elite class of the society. This elite class which was much closed to the British had its grace and own culture. The independence movement played a vital role in the downfall of feudal. Kareem analyzed the main character of this novel that is Rakhshanda Irfan Ali, who belonged to a feudal family of Lucknow, the author successfully portray the rise and fall of this character. In this paper Kareem also defended the technique of novel. He claims that Indirect Interior Monologue technique is used in the novel. He rejects the claim of critics that the novel is written under the technique of Stream of Consciousness. ${ }^{26}$

Raja wrote about Qurutul-Ain Haider's popular novel, Aag Ka Darya and the politics of writings of beyond nation-state. According to Raja, it was anticipated that Aag Ka Darya will gain its right place among the literary circle; instead, the novel was not appreciated academically.

Raja claims that Aag Ka Darya as a post-colonial novel, is very different in its writing techniques and representation. According to him the novel was a literary piece which was way too ahead in 1959 , the year it was published. That's why it was not acclaimed and appreciated that it deserved. By giving examples from past Haider proved that Hindus and Muslims were living together in the Sub-Continent for 3000 years with all their differences and diversities. This interpretation of history was unacceptable for both countries in the situation when partition was happened and nations were divided and this is why the novel was failed to gain the attention of critics. ${ }^{27}$

The above mentioned researches show that the multidimensional writer like Qurutul-Ain Haider was only studied from literature or psychological point of view although most of her writings revolve around sociology and history.

The idea behind this research was to fill this gap by analyzing Qurutul-Ain Haider's selective feminist writings sociologically.

\footnotetext{
${ }^{24}$ Sajjad, Muhammad. "History and Fiction:The Depiction of 1857 in Qurratulain Hyder's Fiction." http://www.academia.edu/19181222_2011.

${ }^{25}$ Oldfield, Anna C. "Confusion in the Universe: Conflict and Narrative inn Quratulain Hyder's River of Fire." The Annual of Urdu Studies, 25, 2010: 28-41.

${ }^{26}$ Jameeluddin Aali,Quratulain Haider: Urdu Fiction Ke Tanazur Mai(Karachi: Mafh Printers and Publishers, $2009), 87$.

${ }^{27}$ Raja, Masood A. “Qurut-ul-AinHaider's River of Fire: The Novel and the Politics of Writing beyond the Nation-State. Interactions 15, (2), 2006:49-60.
} 


\section{Research Question}

This paper is focused on identification of women's oppression in the writings of Quaratul Ain Haider and how did the various forms of women's oppression, such as gender inequality, state of isolation and stratification and deprivation emerged in her writings?

\section{Method and Material}

The research is qualitative in nature so that secondary sources like books, journals, magazines and newspapers were used for analysis and references.

This research was based on analyses of four of Qurat-ul-Ain Haider's short stories namely, Dalan Wala, Yaad Ki Aik Dhanak Jalay, Jilawatan and Singhaardaan.

\section{Analysis}

It is an analysis of an oppressed, isolated and socially controlled woman in patriarchal setup of the Indo Pak Sub-Continent. Haider's female characters were different from the characters of progressive writers. Qurut-ul-Ain sketches women, who become isolated due to the control over them. Haider's women characters were modern, liberal and sometimes poor and backward but all of these women were oppressed in patriarchal setup which prevails in South Asia.

Jilawatan or Banished is a story which mainly rotates around the two leading female characters Kishwari, Kanwal Kumari and one male character that is Dr. Aftab Rai Bahadur. Kishwari belonged to a traditional Muslim family of Jaunpur, where women were not allowed to go out without veil. Muslim families were very restrictive of their girls.

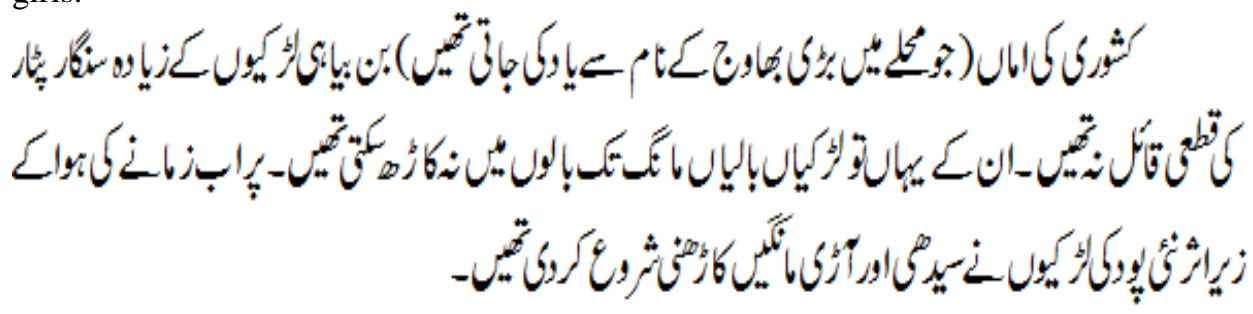

(Haider, 2007)

The mother of Kishwari (who was called Bari Bhawaj(elder sister-in-law)in the whole neighborhood did not like the makeup of unmarried girls. At their home the girls were not even allowed to part their hairs. But now under an influence of modern time the girls of new generation started to part their hairs both from the middle and side. ${ }^{28}$

${ }^{28}$ Quratulain Haider, Patjhar Ki Awaz (Lahore: Sang-e-Meel Publications, 2007), 45. 
These lines show the cultural pressure and tremendous social control which girls were facing in their homes at that time. They were not allowed to beautify themselves and had no control over their bodies.

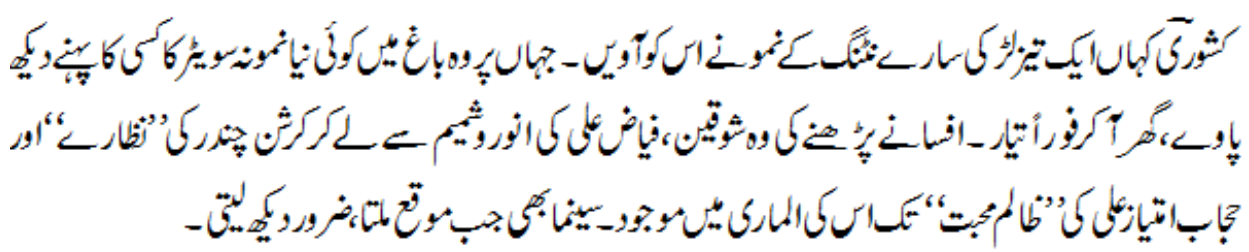

(Haider, 2007)

Kishwari is a sharp girl. She knows all samples of knitting. Whenever she sees a new sample of sweater worn by anyone in the garden, she makes it at once at home. She is fond of reading. From Fayaz Ali's, Anwar and Shamim to Krishan Chandra's, Nazaray and Hijab Imtiaz Ali's Zalim Muhabbat all are present in her cupboard. She goes to cinema, whenever she got the chance. ${ }^{29}$

Kishwari was brought up in a controlled environment but it made her smart and a kind of rebel. When she got engaged to her cousin, Mian Aizaz, she decided in her mind that she would not marry him because to her Mian Aizaz was an image of typical patriarchal mindset.

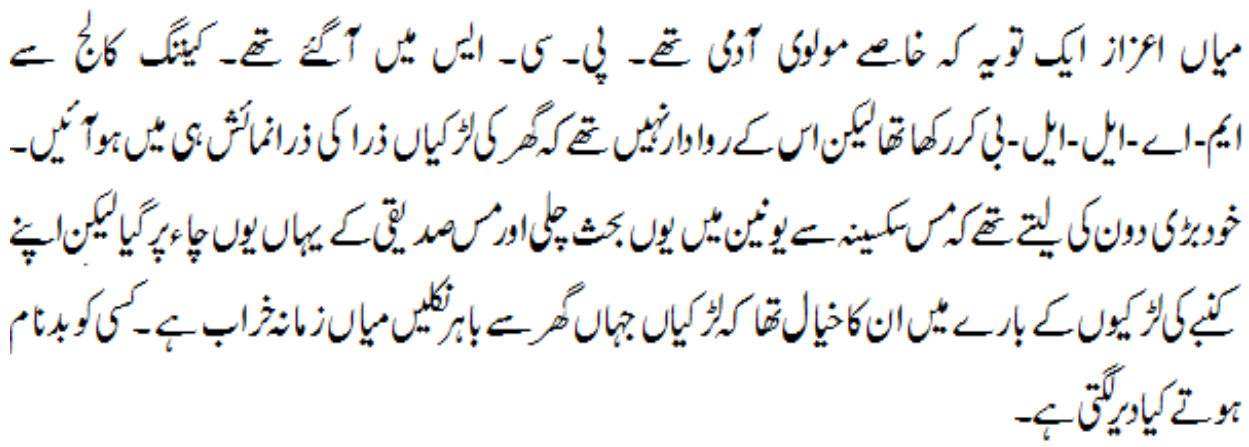

(Haider, 2007)

Haider defined Mian Aizaz's character as a conservative man. Who had done PCS, M.A. and L.L.B from Canning College, but, he was not that indulgent and didn't want the girls of his family to go out freely, even to an exhibition. He himself bragged about how he mixed up with women how he debated with Miss Saksena in the union and how he went for tea with Miss Siddiqui, but for the girls of his family his point of view was rigid.

${ }^{29}$ Ibid. p.59 
The above-mentioned line shows the hypocrisy of the patriarchal mindset, the continuous oppression made Kishwari bold and liberal. She decided not marry Mian Aizaz and planned to refuse at the time of Nikah(marriage ceremony). Saying no at the time of Nikkah to an arranged marriage was and still is the boldest decision a girl could make, as even today majority of girls are married off forcefully in the region. Kishwari was fortunate to have a protective liberal minded brother who supported her views on marriage so she was sent to Lucknow for further studies. ${ }^{30}$

Two important points may be noted here, first a woman could excel only if and when she had a man at her back whether a father, a brother or a husband, secondly, it was patriarchy which dictate that a brother, father or husband made a decision for a woman, she was not trusted enough to make her own independent decisions. So that's how Kishwari escaped her oppressed life.

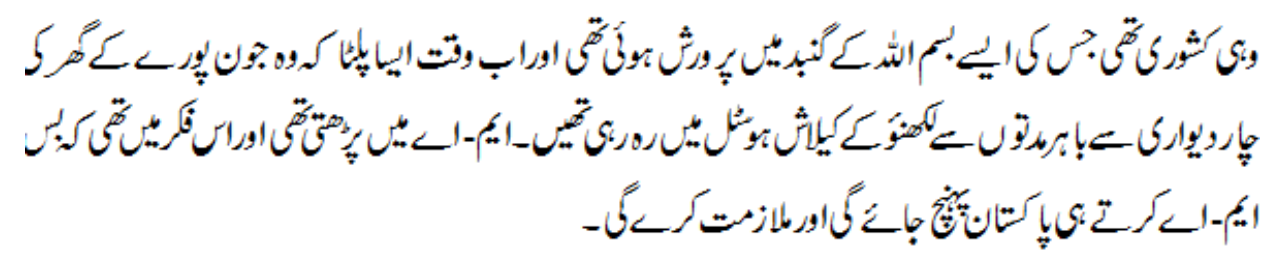

$(\text { Haider, 2007) })^{31}$

Another central figure of the story was Kanwal Kumari, a highly intelligent lady in contrast of Kishwari, she was born in a modern family who studied in convents and University and she had an intellect. Her family was so liberal that there were no boundaries for women to make men friends. She was in love with her class fellow "Aftab Rai”. Aftab didn't proposed Kanwal for marriage and went to London to pursue higher studies and Kanwal got married to ICS officer.

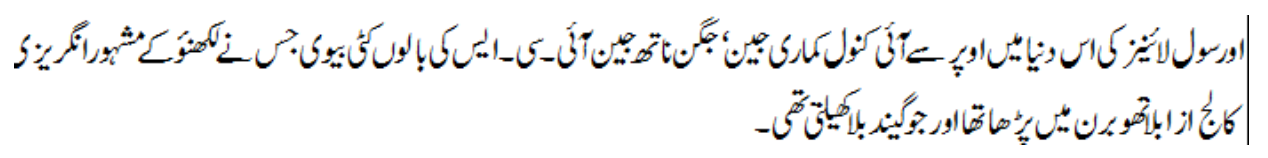

$(\text { Haider, 2007) })^{32}$

And here comes in the world of civil lines, Kanwal Kumari Jain, the bob-cut wife of Jagan Nath I-C-S, who studied from Isabella Thoburn College of Lucknow and who played bat and ball.

\footnotetext{
${ }^{30}$ QuratulainHaider, Patjhar Ki Awaz (Lahore: Sang-e-Meel Publications, 2007). pp.59-66.

${ }^{31}$ Ibid., pp.43-66

${ }^{32}$ Ibid. p.43.
} 
Kanwal Kumari went to England with her husband where she became popular for her intelligent political and philosophical views. She became friends with the high class of England, like Chirostopher Fry (an English poet and scriptwriter), Anthony Asquith (an English film director), Sir Laurence Olivier (a British actor) and Lady Olivier (a British actress). She exchanged views with them on art and literature. ${ }^{33}$

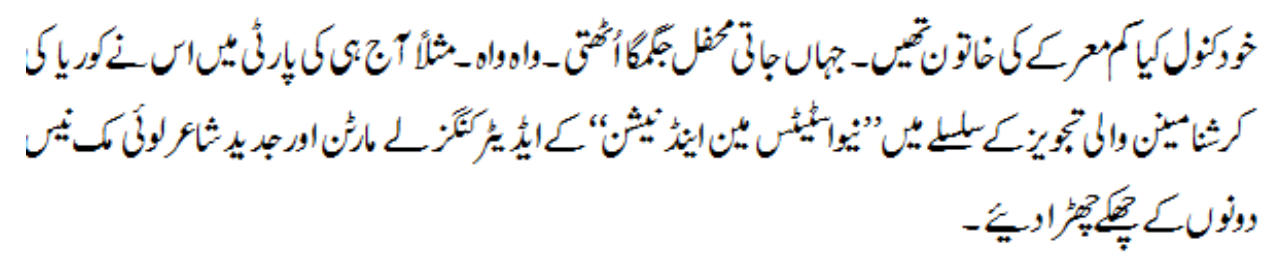

Kanwal Kumari's husband was a low intellect man, Kanwal felt stuck in marriage and used to think of her first love Aftab Rai. It seemed that there was emptiness in her which couldn't be fulfilled by her husband as he was no match to her intellect. This emptiness or inadequateness of her made her isolated. It could easily be avoided if only her lover had little more rapport and less egoistic.

A typical male character in Haider's story was Dr. Aftab Rai, who despite being educated and intelligent had this psyche that though he liked Kanwal Kumari but he never proposed to her although she gave him hints. The male ego in Aftab's character shows a true reflection of a patriarchal system. Kanwal believed that her lover's ego destroyed her life, she was not happy and satisfied and this dissatisfaction led her to a life of seclusion.

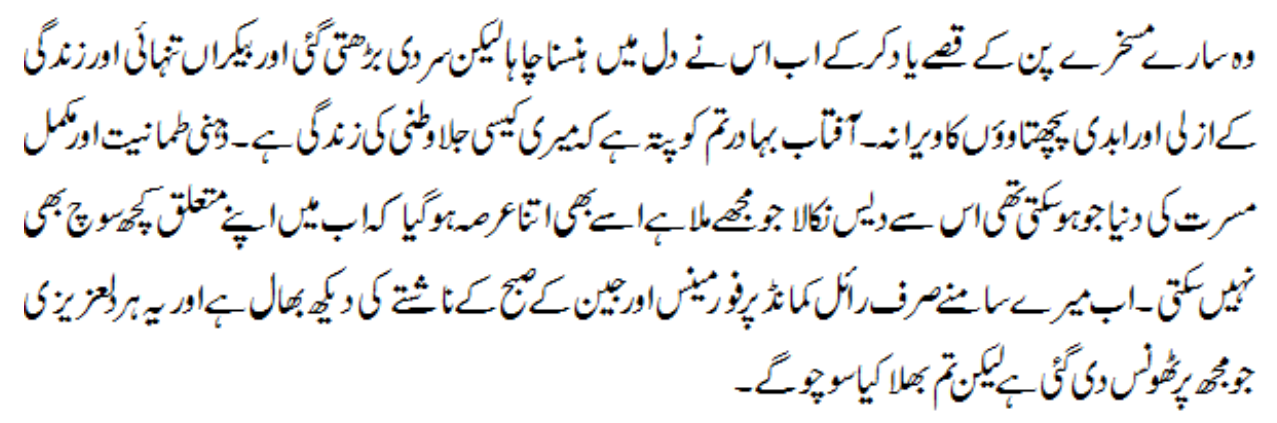

She wanted to laugh by recalling those farcical tales but the cold had increased and an immense solitude and the desert of eternal and endless compunctions of life. Aftab Bahadur do you know how is my exiled life. I have been banished from the world of mental satisfaction and complete happiness, and so much time has been elapsed since that I cannot think about myself. Now, I only have royal command performance and to look after of Jain's breakfast and this popularity which has been imposed on me, oh! But why would you think. ${ }^{34}$

${ }^{33}$ Ibid. p.71
${ }^{34}$ QuratulainHaider, Patjhar Ki Awaz, Op.cit. p.74 
These lines represent the situation of Kanwal who had to sacrifice her life on the ego of man, a common thing in the culture of Sub-continent, most women lead unwanted married life.

Either its Kishwari or Kanwal, both were secluded and were living a life of exile, the only difference was that Kishwari was hopeful for the future whereas Kanwal was hopeless. The feelings of both the characters were expressed beautifully by the writer. A woman who was a victim of patriarchal social system, had lost all hopes in her life, she was in darkness and felt stuck there. On the other hand there was this other character of an independent woman who looked ahead and wanted to change the darkness into the brightness, although she was full of hope but had to go face the same oppression, isolation and struggle.

Dalanwala is another story written by Haider .Dr. Zubaida Siddiqui and Ghafoor Begum are two characters, they were different in status, religion and class but they were all victims of patriarchy and low status. Ghafoor Begum was a maid servant who served a noble family. Her husband, who had a shop of cycles, tied a knot with a young girl last year and from that time Ghafoor Begum spend most of her time in prayers and fasting. ${ }^{35}$

In contrast of Ghafoor Begum the writer presents Dr. Zubaida Siddiqui, was an educated lady who did doctorate from England in a science subject, a rare trait among Muslim women at that time. These two characters are similar to each other regardless of their class and status. Both, when failed to achieve the love of men, lost themselves in religion and prayers. The difference was that Dr.Zubaida found her security in a Hindu man as she was educated and had a high status whereas Ghafoor Begum could not do this because she was illiterate and poor, but they both diverted their attention to God after being hurt by men in their life.

Yaad Ki Aik Dhanak Jalay had a character of "Grace", a maid servant at the Nasir Sahab's home. Grace was a widow; she had a tough life after her husband's death. She had worked as maid, a cloak room's attendant, also worked on a school bus to pick and drop children. When she came to Nasir Sahab's home she became happy as Nasir Sahab and his wife were kind to her. After the death of Mrs.Nasir, Grace was given the duty to look after Nasir Sahab's young son Asghar. She realized that she had become an ultimate part of family; she was enjoying her elevated status until she realized that Nasir Sahab's family wanted him to remarry. The following words show the distress of Grace, who was felling unhappy on the wedding plan of Nasir Sahab.

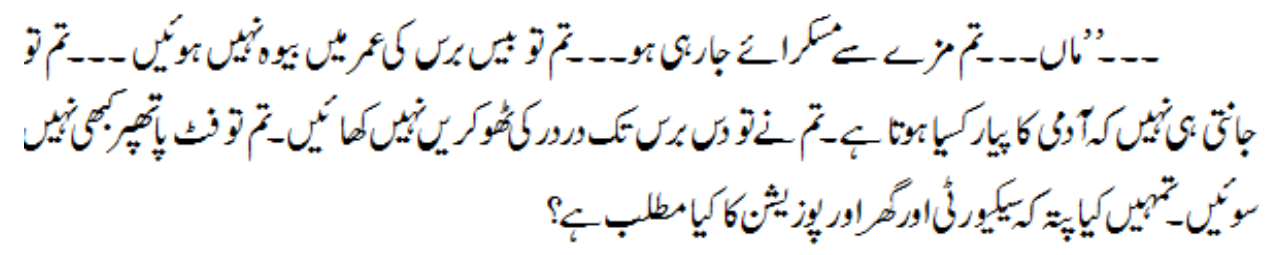

${ }^{35}$ QuratulainHaider, Roshni ki Raftar, Op.cit., pp. 14- 30 
$(\text { Haider, 2007) })^{36}$

Mother you are smiling joyfully....Y You did not become a widow at the age of twenty...... You did not even know the love of a man.....You did not stumbled from door to door for ten years...You have never slept on footpath...How do you know the meaning of home, security and position?

So that is all, security, man's love, position and home, were an ultimate aim of every woman's life. Either a highly qualified Dr.Zubaida or illiterate Ghafoor Begum and Grace; all women felt insecurity in man's world. This was the life of Grace and many of her likes, who do not have home, security and position. They are banished every now and then from their home, the patriarchal societies do not offer security and position to women. Haider $(2007)^{37}$ wrote:

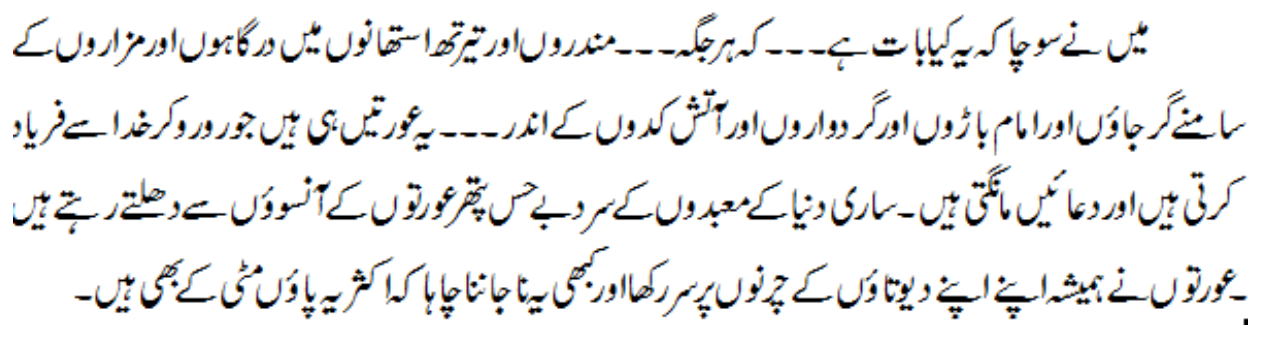

I thought ... why is this ? Everywhere, in temples, sacred places churches, why women are found crying and asking forgiveness from God and praying. All the Gods made of stones are washed by the tears of women; women always place themselves at the feet of their Gods without realizing that those feet were not Gods and sacred but only dust.

Singhardan is a story of a prostitute, Zamarud Pari. The story revolves around prostitution and the society's behavior towards prostitutes.

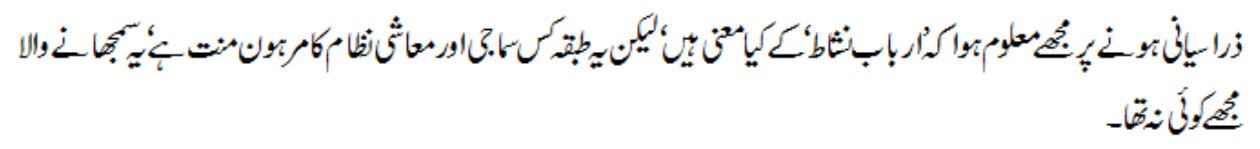

( Zain-udin, 2014) ${ }^{38}$

When I grew older, I got to know the meaning of entertainers and dancers, but nobody told me to which class and social system it was indebted to.

As the story goes Zamarud Pari was told one day that she was admitted to a college in London she was surprised but happy until she realized that she was trapped and was sold to a fat Prince.

${ }^{36}$ QuratulainHaider, Patjhar ki Awaz . Op.cit. pp.97-99

${ }^{37}$ Ibid., pp.115-116

${ }^{38}$ Zain-ud-din, A. Aik Sham ka Doosra Kinara, (Ahmed Brother's Printer, 2014), p.146 


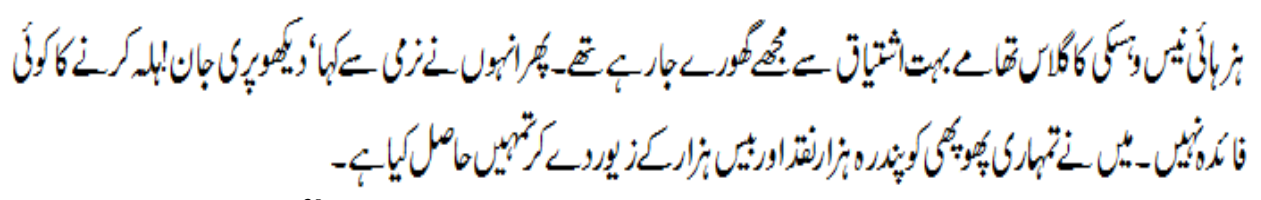

( Zain-ud-din , 2014) $)^{39}$

His Highness, holding a glass of whisky, was staring at me with a strong inclination. Then he said softly, 'look Pari Jan! It is of no use to make fuss. I have given fifteen thousand rupees and jewelry of twenty thousand rupees to your aunt to achieve you.

The author reflects standards of male dominated society and how women were sold and baught and continue to suffer low status in society.

Zamarud Pari went to London with the Prince where they came to know that SubContinent was divided into India and Pakistan. The Prince ran back to India and Zamarud Pari chose to live in England where she started her life afresh.

She studied in the night school and worked in a factory in the daytime. Washed dishes and floors to earn money and meanwhile finished her Montessori training from the night school. But, one day when she went to some party some Indian and Pakistani women recognized her and there she was accused of prostitution in London.

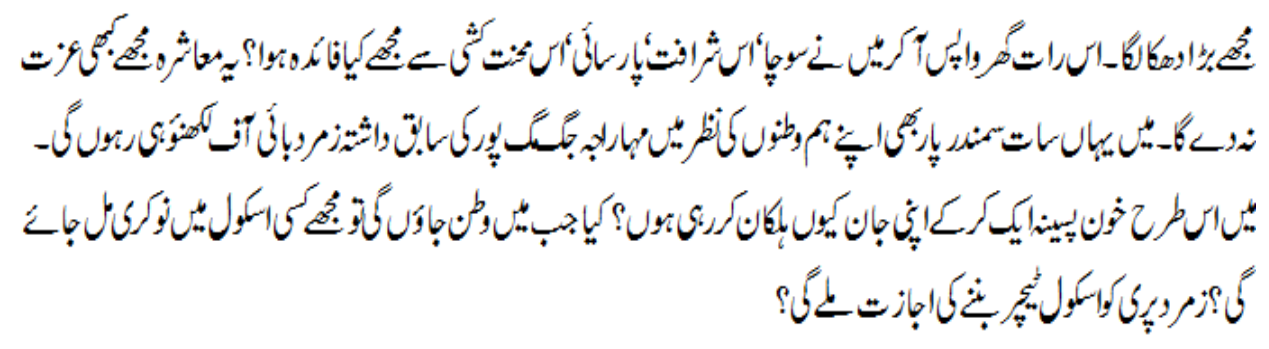

(Zain-ud-din, 2014) ${ }^{40}$

I got a shock. That night when I returned to home I thought, what is the benefit of this nobility, this decorum and hard work? This society will never give me respect. I beyond the seven seas will remain the Zamarud Bai of Lucknow, exmistress of Prince Jagmug Pur, in the eyes of my fellow-countrymen...... Will I get a job in any school when I go back to my country? Will Zamarud Pari ever get permission to become a school teacher?

The crucial question was raised by the writer that why a civilized society restrict a prostitute to turn to a noble profession or elevate her status. Zamarud Pari was compelled to continue her old profession due to the behavior of society.

${ }^{39}$ Ibid., p. 151

${ }^{40}$ Ibid., p.153 
After sometime Zamarud Pari returned to Lucknow for the last time. When she went to "Paristan Manzil" she found a "singhardan" (Jewellary box). She opened it and realized that "This Singhardaan has been included in a beautiful, tragic and grievous part of the Indian history." (Zain-ud-Din, 2014) ${ }^{41}$

\section{Conclusions}

Qurut-ul-Ain Haider is among those writers of Urdu fiction, who continue to influence every generation of writers in South Asia, and is credited for introducing unique narrative technique into the vernacular novel and short story. $^{42}$

This research has explored the portrayal of an independent woman, who is well-educated, learned and intellectual and yet traditional as illustrated in the writings of Qurut-ul-Ain Haider. Sociological variables such as gender inequality, pattern of interaction, state of stratification and deprivation among women were well defined by Haider. She also depicts the situation of women of her time in a great manner that greatly persuades the history of sub-continent. Haider used the broad canvas to highlight the state of women in the Sub-continent. Her style of connecting a social issue to history and anthropology represents her grip over sociology and history.

\section{Suggestions}

It is suggested that sociological studies may be conducted to explore different social issues which are depict in Urdu fiction and poetry. Comparative analysis on pre and post-colonial fictions to analyze different variables relates to women issues is also suggested. Researchers may also study impact of feminism on Urdu fiction, explore and analyze sociological indicators. It may help to understand culture, society and environment in general. Furthermore, it is suggested that Qurut-ul-Ain Haider literary work may be analyzed in detail to know historical social patterns that are clearly illustrated in her writings. Finally it is recommended that along with gender issues, other factors affecting women in different sectors like economy, income disparity, discrimination or harassment at work may also be studied in detail, represented in Urdu fiction by different writers of Urdu language.

${ }^{41}$ Ibid., pp.156-158

${ }^{42}$ Balouch, Akhtar. "Why did Qurut-ul-Ain Hyder Leave Pakistan for India?” Dawn. October 3, 2015. 